\section{MODEL KOMPETEISI JABMTAK

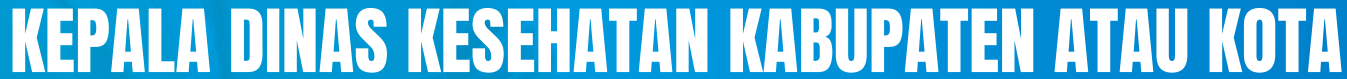

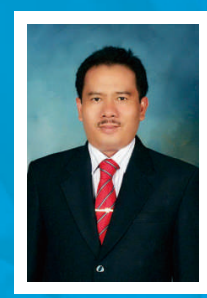

Dr. Rahmat Alyakin Dakhi, SKM, M.Kes, lahir di Hilisimaetano Nias Selatan, Provinsi Sumatera Utara adalah lulusan S1 tahun 1994 FKM USU Medan (1990-1994) dan S2 tahun 1999 di Program Pascasarjana IKM UGM Yogyakarta (1998-1999), serta S3 di FKM USU Medan (2014-2018).

Sebagai Pegawai Negeri Sipil (PNS) dengan pangkat / golongan terakhir Pembina Utama Muda (IV/c), pernah menduduki beberapa jabatan fungsional dan struktural, antara lain: Kepala Sub Bagian Tata Usaha pada Rumah Sakit Umum Daerah (RSUD) Buntok di Kalimantan Tengah (1996-1997), Kepala Sub Bagian Tata Usaha pada Dinas Kesehatan Kabupaten Barito Selatan (19971998), Epidemiolog Ahli pada Balai Teknik Kesehatan Lingkungan dan Pemberantasan Penyakit Menular (BTKL-PPM) Kelas I Medan (2000-2003), Kepala Sub Bagian Tata Usaha pada BTKL-PPM Kelas I Medan (2003-2006), Kepala Bagian Tata Usaha merangkap Pelaksana Tugas Kepala Dinas Kesehatan Kabupaten Nias Selatan (2006-2007), Kepala Dinas Kesehatan Kabupaten Nias Selatan (2007-2010). Saat ini sebagai Dosen Tetap pada Program Pascasarjana Kesehatan Masyarakat Universitas Sari Mutiara Indonesia di Medan.

Pernah mengikuti pendidikan dan pelatihan jabatan struktural dalam berbagai jenjang mulai dari Pendidikan dan Pelatihan (Diklat) ADUM, Diklatpim III sampai Diklatpim II. Pernah juga mengikuti berbagai pelatihan, seminar, dan pertemuan-pertemuan ilmiah yang berhubungan dengan administrasi, manajemen, dan kebijakan kesehatan baik di dalam maupun di luar negeri. Pengalaman short course di luar negeri, antara lain: Policy of Health Administration di Universitas Harvard Amerika Serikat, Management of Epidemiology and Environmental Health di Griffith University di Brisbane Australia, Disaster Management di Tokyo Jepang, dan lain-lain.

Melakukan berbagai penelitian dan pengabdian kepada masyarakat dengan fokus minat riset pada masalah-masalah administrasi, manajemen dan kebijakan kesehatan.

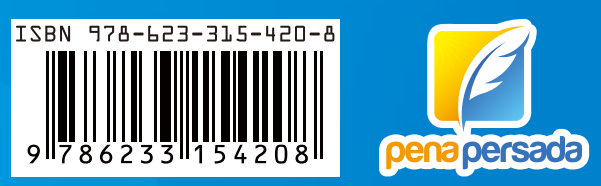

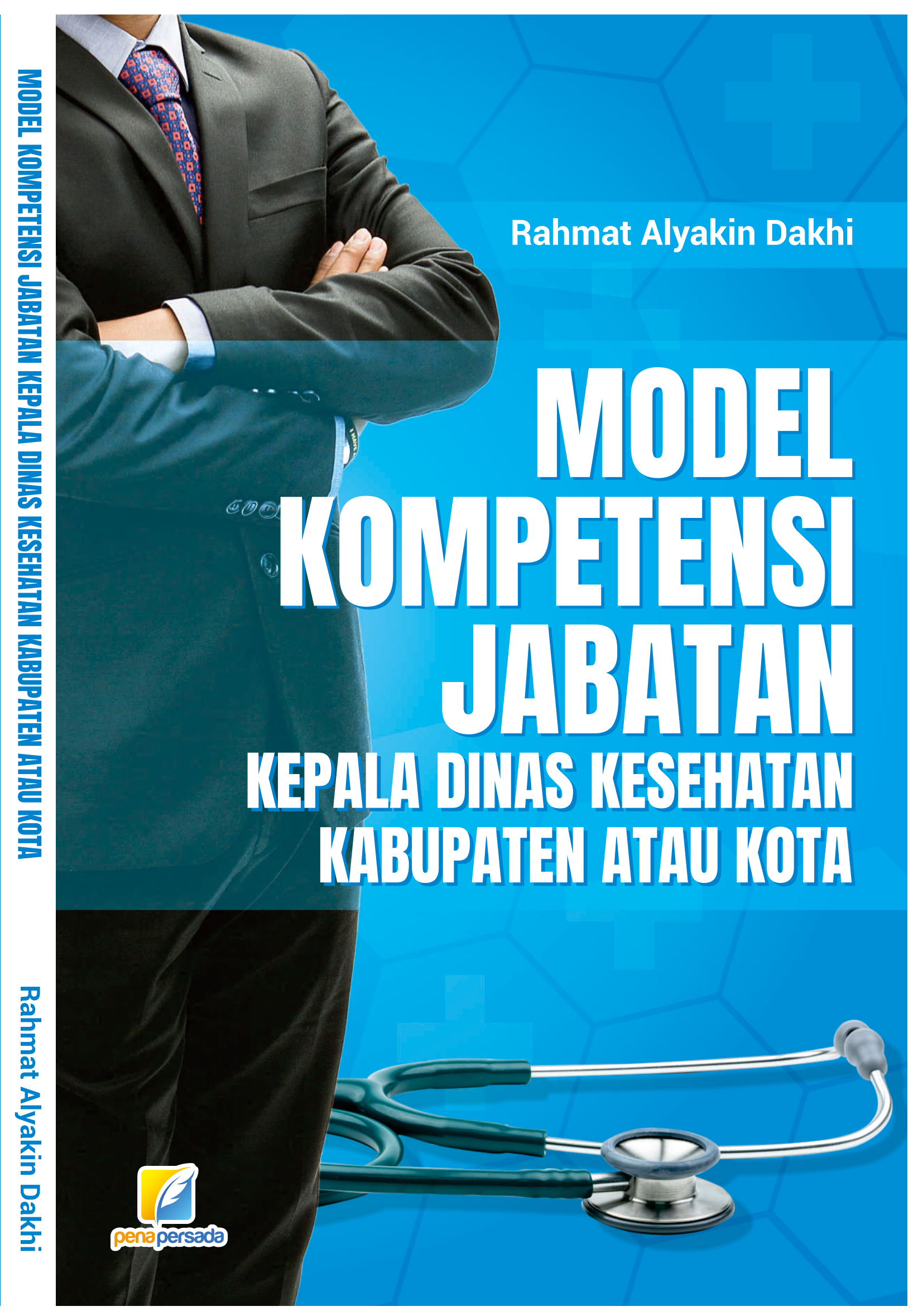




\section{MODEL KOMPETENSI JABATAN KEPALA DINAS KESEHATAN KABUPATEN ATAU KOTA}

RAHMAT ALYAKIN DAKHI

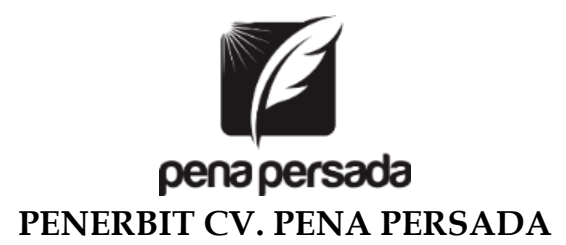




\title{
MODEL KOMPETENSI JABATAN \\ KEPALA DINAS KESEHATAN KABUPATEN ATAU KOTA
}

\author{
Penulis: \\ Rahmat Alyakin Dakhi \\ ISBN : 978-623-315-420-8 \\ Editor: \\ Rusfik Yulli Anur Wati \\ Design Cover : \\ Retnani Nur Briliant
}

Layout :

Eka Safitry

\section{Penerbit CV. Pena Persada}

Redaksi :

Jl. Gerilya No. 292 Purwokerto Selatan, Kab. Banyumas

Jawa Tengah

Email : penerbit.penapersada@gmail.com

Website : penapersada.com Phone : (0281) 7771388

Anggota IKAPI

All right reserved

Cetakan pertama : 2021

Hak Cipta dilindungi oleh undang-undang. Dilarang memperbanyak karya tulis ini dalam bentuk apapun tanpa izin penerbit 


\section{KATA PENGANTAR}

Segala puji senantiasa kita panjatkan kehadirat Allah Swt, atas segala rahmat dan karunianya, akhirnya penulis dapat menyelesaikan penyusunan buku yang berjudul "Model Kompetensi Jabatan Kepala Dinas Kesehatan Kabupaten Atau Kota". Saya menyadari bahwa tanpa bantuan dan bimbingan dari berbagai pihak sangatlah sulit bagi saya untuk menyelesaikan karya ini. Oleh karena itu, saya mengucapkan banyak terima kasih pada semua pihak yang telah membantu penyusunan buku ini. Sehingga buku ini bisa hadir di hadapan pembaca.

Dalam buku ini membahas tentang model kompetensi jabatan kepala dinas kesehatan kabupaten atau kota. Pengukuran dan pengkajian (assesment) kompetensi jabatan Kepala Dinas Kesehatan Kabupaten atau Kota dilakukan melalui suatu standar kompetensi yang merupakan persyaratan yang harus dimiliki dalam melaksanakan tugas pokok dan fungsi jabatan Kepala Dinas Kesehatan Kabupaten atau Kota. Kompetensi Kepala Dinas Kesehatan Kabupaten atau Kota merupakan kemampuan dan karakteristik yang dimiliki berupa pengetahuan, keterampilan atau keahlian, dan sikap perilaku yang diperlukan dalam menjalankan tugas-tugas dan fungsi jabatannya selaku Kepala Dinas Kesehatan Kabupaten atau Kota. Berdasarkan uji kompetensi, dapat diketahui apakah seseorang yang menduduki jabatan Kepala Dinas Kesehatan Kabupaten atau Kota telah memiliki kompetensi tertentu yang dipersyaratkan, jika belum memiliki kompetensi yang disyaratkan, dapat dilakukan pengembangan kompetensi tersebut dengan cara pelatihan, atau perlu dilakukan mutasi sehingga kompetensi juga bermanfaat untuk training need analysis.

Penulis menyadari bahwa buku ini masih jauh dari kesempurnaan. Oleh karena itu kritik dan saran yang membangun sangat dibutuhkan guna penyempurnaan buku ini. Akhir kata saya berharap Allah Swt berkenan membalas segala kebaikan semua pihak yang telah membantu.

Penulis 


\section{DAFTAR ISI}

KATA PENGANTAR ................................................................ iii

DAFTAR ISI .................................................................................

BAB I Pendahuluan ........................................................................ 1

A. Hak Asasi Kesehatan di Indonesia ...................................... 1

B. Kompetensi Kepala Dinas Kesehatan Kabupaten atau Kota......................................................................................... 4

C. Kinerja Pembangunan Kesehatan Masyarakat Antar Kabupaten Atau Kota............................................................. 6

BAB II PEMERINTAHAN DAERAH ......................................... 11

A. Otonomi dan Perangkat Pemerintah Daerah.................... 11

B. Tugas dan Wewenang Daerah di bidang Kesehatan........ 14

C. Dinas Kesehatan Daerah...................................................... 16

BAB III KOMPETENSI ............................................................. 22

A. Pengertian Kompetensi..................................................... 22

B. Pengukuran Kompetensi. .................................................. 33

BAB IV DIMENSI KOMPETENSI KEPEMIMPINAN ....................36

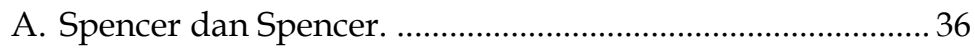

B. American College of Healthcare Executives (ACHE)....... 43

C. United States Department of Health and Human Service. 44

D. American Organization of Nurse Executives (AONE) .....46

E. The Northern Ireland Practice and Education Council for Nursing and Midwifery (NIPEC)................................... 47

F. Aspek Juridis Standar Kompetensi Jabatan Kepala Dinas Kesehatan............................................................................. 49

G. Dimensi Kepemimpinan Lokal..................................... 56 
BAB V PERMODELAN KOMPETENSI .65

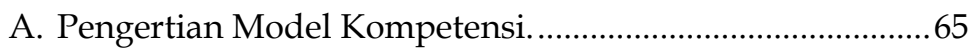

B. Tahapan Permodelan Kompetensi. .........................................67

BAB VI DIMENSI DAN INDIKATOR KOMPETENSI JABATAN KEPALA DINAS KESEHATAN ...............................................76

A. Prestasi dan Tindakan ............................................................

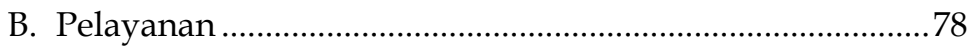

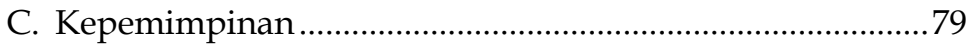

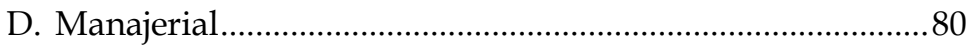

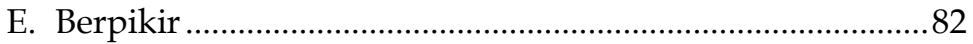

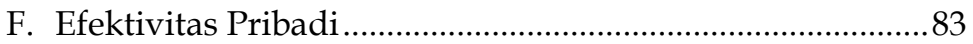

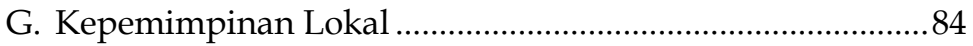

BAB VII PENGUKURAN KOMPETENSI JABATAN KEPALA DINAS KESEHATAN KABUPATEN ATAU KOTA................86

A. Gambaran Umum Provinsi Sumatera Utara ..........................86

B. Pendekatan Kualitatif (Model Pertama) Kompetensi Jabatan Kepala Dinas Kesehatan Kabupaten atau Kota. ...89

C. Pendekatan Kuantitatif (Model Kedua) Kompetensi Jabatan Kepala Dinas Kesehatan Kabupaten atau Kota. ...98

BAB VIII KOMPETENSI JABATAN KEPALA DINAS KESEHATAN KABUPATEN ATAU KOTA............................100

A. Kompetensi Prestasi dan Tindakan......................................102

B. Kompetensi Membantu dan Melayani...................................115

C. Kompetensi Kepemimpinan..................................................119

D. Kompetensi Manajerial. ......................................................123

E. Kompetensi Berpikir...........................................................124

F. Kompetensi Efektivitas Pribadi............................................125 
G. Kompetensi Kepemimpinan Lokal..................................... 130

H. Kebaruan (novelty) .............................................................. 132

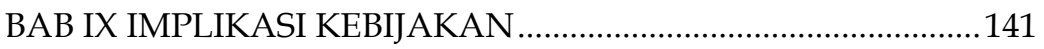

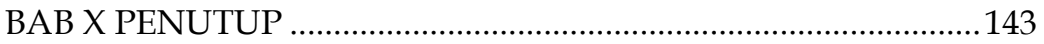

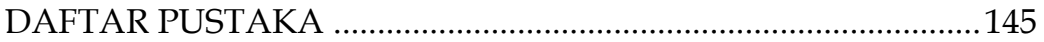

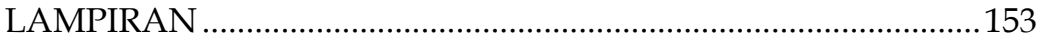




\section{BAB I \\ Pendahuluan}

\section{A. Hak Asasi Kesehatan di Indonesia}

Kesehatan merupakan hak asasi manusia sebagaimana tercantum dalam konstitusi World Health Organization (WHO) tahun 1946 yang menyatakan bahwa setiap orang memiliki hak atas informasi kesehatan, privasi, menikmati teknologi kesehatan, ketersediaan makanan dan gizi, mencapai jaminan standar hidup optimal dan jaminan sosial. Hak asasi kesehatan tersebut di Indonesia telah ditegaskan dalam Undang-Undang Dasar (UUD) 1945 bahwa setiap orang berhak untuk hidup sejahtera lahir batin, bertempat tinggal serta memperoleh pelayanan kesehatan. Kesehatan juga merupakan salah satu unsur kesejahteraan umum dari tujuan nasional bangsa Indonesia sebagaimana termaktub dalam Pembukaan UUD 1945. Penyelenggaraan pembangunan kesehatan merupakan investasi untuk keberhasilan pembangunan suatu bangsa karena Sumber Daya Manusia (SDM) yang sehat merupakan jaminan kesinambungan pembangunan bangsa.

Kesehatan yang dalam Undang-Undang (UU) Nomor 36 Tahun 2009 tentang Kesehatan didefinisikan sebagai keadaan sehat, baik secara fisik, mental, spiritual maupun sosial yang memungkinkan setiap orang untuk hidup produktif secara sosial dan ekonomis, merumuskan bahwa orientasi penyelenggaraan berbagai upaya kesehatan tidak terbatas hanya pada upaya-upaya mensejahterakan fisik, mental, dan sosial tetapi juga spiritual sehingga setiap penduduk memiliki kualitas hidup yang produktif baik secara sosial maupun secara ekonomi. 
Mewujudkan derajat kesehatan yang optimal dilakukan dengan berbagai pendekatan, baik pendekatan promotif, preventif, kuratif, dan rehabilitatif. Pada beberapa dasawarsa terakhir menunjukkan paradigma pembangunan kesehatan telah mengalami perubahan dari "health for survival" yang berorientasi pada orang sakit dan mengutamakan berbagai upaya kuratif dan rehabilitatif menjadi "health for human development" yang mengutamakan orang sehat dan berorientasi pada berbagai upaya promotif dan preventif. Selaras dengan itu indikator kinerja pembangunan kesehatan tidak lagi terbatas hanya pada berbagai indikator pelayanan medis semata, tetapi juga berbagai indikator pelayanan kesehatan masyarakat seperti perilaku, penyakit menular, kesehatan lingkungan, dan kepemimpinan kesehatan. Oleh sebab itu, kinerja pembangunan kesehatan dengan pendekatan paradigma"health for human development" diarahkan pada peningkatan peranan kepemimpinan kesehatan dalam berbagai aspek pembangunan kesehatan terlebih bahwa kepemimpinan kesehatan masyarakat bersifat komplementer dengan pendekatan kepemimpinan medis atau kedokteran. Pendekatan ini juga merupakan konsekuensi bahwa upaya kesehatan dilakukan melalui berbagai pendekatan yang bersifat multi dimensi, multi sektoral dan bahkan multi disiplin keilmuan secara komprehensif karena paradigma ini memposisikan masyarakat bukan hanya sebagai objek pembangunan kesehatan tetapi juga sebagai subyek pembangunan kesehatan itu sendiri.

Definisi Ilmu Kesehatan Masyarakat sebagaimana dikemukakan Winslow (1920) yang dikutip Ede dan Amal (2017) merumuskan bahwa Ilmu Kesehatan Masyarakat adalah ilmu dan seni mencegah penyakit, memperpanjang hidup, meningkatkan kesehatan fisik dan mental, dan efisiensi melalui usaha masyarakat yang terorganisir untuk meningkatkan sanitasi lingkungan, pengendalian infeksi di masyarakat, pendidikan individu tentang kebersihan perorangan, pengorganisasian pelayanan medis dan 
perawatan, untuk diagnosa dini, pencegahan penyakit dan pengembangan aspek sosial, yang akan mendukung agar setiap orang di masyarakat mempunyai standar kehidupan yang kuat untuk menjaga kesehatannya. Mengacu pada definisi tersebut maka pengorganisasian masyarakat dan pengorganisasian pelayanan medis dan perawatan merupakan proses penting dalam upaya diagnosa dini, pencegahan penyakit dan pengembangan aspek sosial yang di era otonomi daerah dewasa ini aktor utamanya adalah organisasi Dinas Kesehatan Daerah.

Kepemimpinan organisasi Dinas Kesehatan Kabupaten atau Kota merupakan unsur penting dan strategis dalam menentukan kinerja pembangunan kesehatan nasional mengingat bahwa kinerja pembangunan kesehatan nasional merupakan hasil kumulatif dari kinerja pembangunan kesehatan daerah. Istianto (2011) menegaskan bahwa pada sebuah organisasi pemerintahan, keberhasilan atau kegagalan dalam pelaksanaan tugas dan penyelenggaraan pemerintahan, dipengaruhi oleh kepemimpinan. Kapasitas organisasi yang didukung oleh kepemimpinan yang baik akan menghasilkan kinerja organisasi pemerintahan yang baik, sebaliknya kelemahan kepemimpinan merupakan salah satu sebab keruntuhan kinerja organisasi pemerintah di Indonesia. Pemimpin bertanggung jawab terhadap segala sesuatu yang berhubungan dengan organisasi yang dipimpinnya.

Kepemimpinan kesehatan juga merupakan unsur Manajemen Sumber Daya Manusia (SDM) Kesehatan yang merupakan salah satu pilar Sistem Kesehatan Nasional (SKN) sebagaimana tercantum dalam Peraturan Presiden RI Nomor 72 Tahun 2012 tentang Sistem Kesehatan Nasional. Kepemimpinan kesehatan berperan dominan dalam keberhasilan penyelenggaraan berbagai upaya kesehatan. Kinerja organisasi kesehatan akan baik apabila pemimpinnya memiliki kompetensi yang memadai dalam menjalankan fungsi-fungsi organisasi, sebaliknya apabila pemimpin tidak 
memiliki kompetensi yang memadai maka akan timbul berbagai persoalan yang dapat menghambat atau mempengaruhi kinerja organisasi.

\section{B. Kompetensi Kepala Dinas Kesehatan Kabupaten atau Kota}

Istilah kompetensi di bidang pekerjaan untuk pertama sekali muncul sekitar awal tahun 1970-an ketika seorang ilmuwan Amerika Serikat menerbitkan sebuah artikel yang berjudul "Testing for Competence rather than Intelligence" (menguji kompetensi bukannya inteligensi). Menurut Spencer dan Spencer (1993), pengujian kompetensi pertama sekali dilakukan oleh Kementerian Luar Negeri Amerika Serikat dalam menyeleksi calon pegawai pada bagian pelayanan informasi luar negeri atau Foreign Service Information Officer (FSIO). Metode seleksi yang sebelumnya didasarkan pada pengujian inteligensi dan prestasi akademik ternyata tidak mampu memberikan perkiraan yang tepat terhadap keberhasilan FSIO pada saat bekerja sehingga akhirnya diganti menjadi pengujian kompetensi.

Kompetensi Kepala Dinas Kesehatan Kabupaten atau Kota dapat diartikan sebagai kemampuan dan karakteristik yang dimiliki oleh Kepala Dinas Kesehatan Kabupaten atau Kota berupa pengetahuan, keterampilan atau keahlian, dan sikap perilaku yang diperlukan dalam menjalankan tugastugas dan fungsi jabatannya selaku Kepala Dinas Kesehatan Kabupaten atau Kota. Kompetensi merupakan kombinasi antara keterampilan, karakter pribadi, dan pengetahuan yang tercermin melalui kinerja Dinas Kesehatan Kabupaten atau Kota yang dapat diamati, diukur dan dievaluasi. Kompetensi kepemimpinan kesehatan dapat dibedakan menjadi 2 bagian, yakni: soft competency yang berkaitan dengan kemampuan untuk mengelola pekerjaan di bidang kesehatan dan membangun interaksi dengan orang lain dan hard competency yang berkaitan dengan kemampuan fungsional atau teknis di bidang kesehatan. Kompetensi teknis bidang kesehatan tidak 
hanya diartikan sebagai kemampuan (capability) atau keahlian (expertise) dan keterampilan (skill) semata, namun lebih merupakan hasil dari pengalaman yang melibatkan pemahaman atau pengetahuan, tindakan nyata serta proses mental yang terjadi dalam jangka waktu tertentu serta berulang-ulang sehingga menghasilkan kemampuan atau keahlian di bidang kepemimpinan kesehatan.

Pengukuran dan pengkajian (assesment) kompetensi jabatan Kepala Dinas Kesehatan Kabupaten atau Kota dilakukan melalui suatu standar kompetensi yang merupakan persyaratan yang harus dimiliki dalam melaksanakan tugas pokok dan fungsi jabatan Kepala Dinas Kesehatan Kabupaten atau Kota. Seseorang bisa saja memiliki keterampilan dan pengetahuan yang memadai di bidang kesehatan, tetapi hal itu bukan jaminan bahwa yang bersangkutan akan bekerja sesuai dengan kemampuannya itu. Pendekatan kompetensi menggali lebih jauh mengenai motif, watak dan konsep diri yang mendasari seseorang untuk dapat mempergunakan pengetahuan dan keterampilannya secara maksimal dalam bekerja. Robin dan Timothy (2010) mengatakan bahwa kajian kompetensi mampu memprediksi kinerja dalam jabatan atau profesi di masa yang akan datang. Standar Kompetensi Jabatan Kepala Dinas Kesehatan Kabupaten atau Kota juga bermanfaat untuk membantu dalam melakukan evaluasi atau penilaian kinerja Kepala Dinas Kesehatan Kabupaten atau Kota. Identifikasi kompetensi yang akurat dapat dipergunakan sebagai tolok ukur kemampuan seseorang dalam jabatan Kepala Dinas Kesehatan Kabupaten atau Kota. Berdasarkan uji kompetensi, dapat diketahui apakah seseorang yang menduduki jabatan Kepala Dinas Kesehatan Kabupaten atau Kota telah memiliki kompetensi tertentu yang dipersyaratkan, jika belum memiliki kompetensi yang disyaratkan, dapat dilakukan pengembangan kompetensi tersebut dengan cara pelatihan, atau perlu dilakukan mutasi sehingga kompetensi juga bermanfaat untuk training need analysis. 


\section{Kinerja Pembangunan Kesehatan Masyarakat Antar Kabupaten Atau Kota}

Provinsi Sumatera Utara merupakan Provinsi ke-4 berpenduduk terbanyak di Indonesia dan Provinsi berpenduduk terbesar di luar Pulau Jawa dengan jumlah penduduk 14.102.911 jiwa (BPS, 2017) dengan berbagai keanekaragaman suku, budaya, dan bahasa daerah. Kinerja pembangunan di Provinsi Sumatera Utara dapat dilihat berdasarkan Indeks Pembangunan Kesehatan Masyarakat (IPKM) yang merupakan kumpulan indikator kesehatan yang dapat menggambarkan keberhasilan pembangunan kesehatan baik secara langsung maupun tidak langsung. Berdasarkan indikator IPKM, tahun 2013 Provinsi Sumatera Utara menempati urutan ke-10 dari 33 Provinsi di Indonesia. Hal ini menunjukkan bahwa IPKM Provinsi Sumatera Utara dibandingkan dengan Provinsi lain di Indonesia masih jauh dari yang diharapkan. Selain itu, pada tahun 2018 dari 100 Kabupaten atau Kota di Indonesia yang menjadi sasaran intervensi pemerintah pusat karena terjadinya anak kerdil (stunting) terdapat 4 Kabupaten atau Kota di Provinsi Sumatera Utara yaitu Langkat dengan prevalensi 55.48\%, Padang Lawas dengan prevalensi 54.86\%, Nias Utara dengan prevalensi $54.83 \%$, dan Gunungsitoli dengan prevalensi $52.32 \%$.

Capaian pembangunan kesehatan di Provinsi Sumatera Utara yang masih rendah, semakin tertantang dengan adanya kesenjangan keberhasilan pembangunan kesehatan masyarakat antar Kabupaten atau Kota di Provinsi Sumatera Utara. Kesenjangan tersebut dapat diketahui berdasarkan indikator IPKM 2013. Kisaran IPKM Kabupaten atau Kota di Provinsi Sumatera Utara tahun 2010 berada pada 0,36900,6511 dengan posisi Kabupaten atau Kota menempati peringkat 12 sampai dengan 486 dari 497 Kabupaten atau Kota di Indonesia. Keadaan ini tidak jauh berbeda dengan indikator IPKM tahun 2018. Kesenjangan ini merupakan tantangan tersendiri dalam mencapai berbagai target yang 
telah ditetapkan dalam Tujuan Pembangunan Berkelanjutan (Sustainable Development Goals atau SDGs). Keberhasilan SDGs tidak terlepas dari peranan Pemerintah Kabupaten atau Kota karena berada lebih dekat dengan warganya, memiliki wewenang dan dana, dapat melakukan berbagai inovasi, serta merupakan ujung tombak penyedia pelayanan kesehatan dan berbagai kebijakan serta program kesehatan.

Kesenjangan kinerja pembangunan kesehatan antar Kabupaten atau Kota di Provinsi Sumatera Utara dan juga provinsi lain di Indonesia merupakan indikasi kesenjangan kompetensi Kepala Dinas Kesehatan Kabupaten atau Kota, karena sebagaimana dikemukakan sebelumnya bahwa keberhasilan atau kegagalan organisasi Dinas Kesehatan Kabupaten atau Kota dipengaruhi oleh kompetensi Kepala Dinas Kesehatan Kabupaten atau Kota sebagai pimpinan organisasi. Oleh sebab itu sangatlah beralasan ketika UU Nomor 5 Tahun 2014 tentang Aparatur Sipil Negara menegaskan bahwa pengembangan karir Aparatur Sipil Negara (ASN) yang dalam hal ini termasuk jabatan Kepala Dinas Kesehatan Kabupaten atau Kota dilakukan berdasarkan kompetensi.

Kebijakan tersebut juga merupakan upaya untuk mewujudkan penyelenggaraan pembangunan di bidang kesehatan melalui pemerintahan yang baik (good governance). Kenyataan menunjukkan bahwa sejak penerapan otonomi daerah pengangkatan seseorang dalam jabatan Kepala Satuan Kerja Perangkat Daerah (SKPD) atau yang saat ini dikenal sebagai Organisasi Perangkat Daerah (OPD) termasuk jabatan Kepala Dinas Kesehatan Kabupaten atau Kota kurang memperhatikan aspek kompetensi. Setelah pergantian Kepala Daerah, Kepala Dinas Kesehatan juga mengalami pergantian bahkan ada yang di-nonjob-kan dan diganti dengan PNS lain yang memiliki kedekatan dengan Kepala Daerah tanpa mempertimbangkan aspek kompetensi yang bersangkutan. Perlunya kedekatan dengan Kepala Daerah didasari asumsi bahwa jabatan adalah kepercayaan; walaupun asumsi 
tersebut tidak memiliki dasar legalitas tetapi fenomena inilah yang sering dipraktekkan. Keadaan ini diperparah lagi dengan kenyataan bahwa pengembangan karier ASN dilakukan melalui pendekatan senioritas kepangkatan sehingga melahirkan ASN yang lebih berorientasi pada mengejar senioritas kepangkatan daripada berupaya meningkatkan dan mengembangkan kompetensi sesuai dengan jabatan yang diembannya. Mekanisme pengangkatan, pemindahan, dan pemberhentian ASN dalam jabatan Kepala Dinas Kesehatan Kabupaten atau Kota yang dilakukan secara terbuka dengan mempertimbangkan aspek kompetensi diharapkan dapat mengeliminir intervensi politik dalam penempatan pejabat birokrasi, menghapus praktek-praktek negatif dalam pengangkatan pejabat seperti jual beli jabatan, menghindari pengangkatan pejabat yang tidak sesuai kompetensi dan pemberian jabatan sebagai balas budi, serta praktek-praktek lainnya yang tidak sesuai kaidah-kaidah good governance.

Diberlakukannya UU Nomor 5 Tahun 2014 tentang Aparatur Sipil Negara merupakan babak baru di Indonesia dalam kebijakan dan manajemen SDM Kepemimpinan ASN dari sistem karir tertutup (closed career system) menjadi sistem karir terbuka (open career system) sekaligus menjadi solusi terbaik dalam penanggulangan praktik pengangkatan pimpinan tinggi dalam berbagai organisasi pemerintah oleh Kepala Daerah termasuk jabatan Kepala Dinas Kesehatan Kabupaten atau Kota selama ini yang lebih cenderung like and dislike.

Pengisian jabatan Kepala Dinas Kesehatan Kabupaten atau Kota sebagai Pimpinan Tinggi Pratama dilakukan secara terbuka dan kompetitif di antara ASN berdasarkan kompetensi. Teknis pelaksanaannya telah dijabarkan lebih lanjut dalam Peraturan Menteri PAN dan RB Nomor 13 tahun 2014 tentang Tata Cara Pengisian Jabatan Pimpinan Tinggi di Lingkungan Instansi Pemerintah. 
Kenyataan menunjukkan bahwa kebijakan seleksi dan pengembangan karir ASN termasuk untuk menduduki jabatan Kepala Dinas Kesehatan Kabupaten atau Kota dalam UU tersebut dalam penerapannya bervariasi antara daerah yang satu dengan daerah lainnya. Hal ini disebabkan belum jelasnya substansi ataupun materi uji kompetensi dalam bentuk dimensi dan indikator terutama dalam memilih, mengangkat, menetapkan maupun menilai kelayakan ASN dalam jabatan Kepala Dinas Kesehatan Kabupaten atau Kota. Kompetensi teknis yang diukur dari tingkat dan spesialisasi pendidikan, pelatihan teknis fungsional, dan pengalaman bekerja secara teknis; kompetensi manajerial yang diukur dari tingkat pendidikan, pelatihan struktural atau manajemen, dan pengalaman kepemimpinan; dan kompetensi sosial kultural yang diukur dari pengalaman kerja berkaitan dengan sosial kemasyarakatan selain menimbulkan multitafsir juga belum dapat dioperasionalisasikan dalam suatu standar kompetensi kepemimpinan.

Permenkes Nomor 971/Menkes/Per/XI/2009 tentang Standar Kompetensi Pejabat Struktural Kesehatan yang ditetapkan sebelum lahirnya UU Nomor 5 Tahun 2014 tentang Aparatur Sipil Negara tentu saja perlu ditinjau kembali agar dapat dijadikan sebagai penjabaran kompetensi teknis, kompetensi manajerial, dan kompetensi sosial kultural sebagaimana dimaksud dalam UU Nomor 5 Tahun 2014 tentang Aparatur Sipil Negara termasuk untuk jabatan Kepala Dinas Kesehatan Kabupaten atau Kota.

Fungsi utama ilmu kesehatan masyarakat dalam buku The Future of Public Health yang diterbitkan Institute of Medicine (dalam Ede dan Amal, 2017) adalah asessment (pengkajian), policy development (pengembangan kebijakan), dan assurance (jaminan). Kajian (assessment) terhadap kompleksitas organisasi dan beragamnya urusan pemerintahan di bidang kesehatan di daerah yang cenderung semakin rumit, perkembangan tuntutan dan kebutuhan masyarakat terhadap pelayanan kesehatan semakin berkembang dalam nuansa 
otonomi daerah, kemajuan teknologi kedokteran dan kesehatan yang pesat serta situasi globalisasi dunia, dan kesenjangan kinerja pembangunan di bidang kesehatan diharapkan menghasilkan dimensi dan indikator pembentuk model kompetensi yang dapat dipergunakan sebagai standar minimal dalam memilih, mengangkat, menetapkan maupun menilai kelayakan ASN dalam jabatan Kepala Dinas Kesehatan Kabupaten atau Kota. Perubahan kebijakan dari sistem karir tertutup menjadi sistem karir terbuka sebagaimana diamanatkan dalam UU Nomor 5 Tahun 2014 tentang Aparatur Sipil Negara memerlukan pengembangan kebijakan (policy development) dalam bentuk Permenkes tentang Standar Kompetensi Jabatan Kepala Dinas Kesehatan Kabupaten atau Kota yang sekaligus sebagai penyesuaian Permenkes Nomor 971/Menkes/Per/XI/2009 tentang Standar Kompetensi Pejabat Struktural Kesehatan terhadap UU Nomor 5 Tahun 2014 tentang Aparatur Sipil Negara. Penetapan Standar Kompetensi Jabatan Kepala Dinas Kesehatan Kabupaten atau Kota oleh pemerintah merupakan jaminan (assurance) dihasilkannya Kepala Dinas Kesehatan Kabupaten atau Kota yang memenuhi standar kompetensi yang diharapkan sehingga berbagai masalah tersebut $\mathrm{di}$ atas dapat ditanggulangi dan diantisipasi sedini mungkin. Hal inilah yang melatarbelakangi penggalian, identifikasi, dan konfirmasi dimensi dan indikator pembentuk model kompetensi Jabatan Kepala Dinas Kesehatan Kabupaten atau Kota ini dilakukan. 


\section{BAB II \\ PEMERINTAHAN DAERAH}

Pembangunan kesehatan nasional merupakan resultante pembangunan kesehatan di berbagai daerah di Indonesia. Pembangunan kesehatan pada era otonomi daerah sangat tergantung pada kapasitas aparatur pemerintah daerah dalam menyelenggarakan berbagai upaya kesehatan di daerah untuk mencapai derajat kesehatan masyarakat yang optimal. Pada bagian ini diuraikan konsep otonomi daerah dan perangkatnya, tugas dan wewenang daerah di bidang kesehatan serta peranan, tugas pokok dan fungsi organisasi Dinas Kesehatan di daerah.

\section{A. Otonomi dan Perangkat Pemerintah Daerah.}

Otonomi daerah adalah hak, wewenang, dan kewajiban daerah otonom untuk mengatur dan mengurus sendiri urusan pemerintahan dan kepentingan masyarakat setempat sesuai dengan peraturan perundang-undangan. Secara harfiah, otonomi daerah berasal dari kata otonomi dan daerah. Berdasarkan bahasa Yunani, otonomi berasal dari kata autos dan nomos. Autos berarti sendiri dan nomos berarti pemerintah. Pengertian "otonom" secara bahasa adalah "berdiri sendiri" atau "dengan pemerintahan sendiri" sedangkan "daerah" adalah suatu "wilayah" atau "lingkungan pemerintah". Istilah otonomi daerah adalah wewenang atau kekuasaan pada suatu wilayah atau daerah yang mengatur dan mengelola untuk kepentingan wilayah atau daerah masyarakat itu sendiri. Hakikat otonomi daerah adalah wewenang, hak dan kewajiban daerah untuk mengatur dan mengurus rumah tangganya sendiri sesuai dengan perundang-undangan yang berlaku. Otonomi daerah adalah perwujudan dari pelaksanaan urusan pemerintah berdasarkan asas desentralisasi yakni penyerahan urusan pemerintah kepada daerah untuk mengurus rumah tangganya sendiri. 
Istilah otonomi daerah memiliki makna yang berbeda dengan desentralisasi. Menurut Hendratno (2009), istilah otonomi lebih cenderung berada dalam aspek politikkekuasaan negara sedangkan desentralisasi lebih cenderung berada dalam aspek administrasi negara. Antara desentralisasi dengan otonomi daerah mempunyai hubungan yang sangat erat sehingga sangat susah untuk dipisahkan antara keduanya karena otonomi daerah lahir karena adanya desentralisasi. Otonomi daerah merupakan persoalan kewenangan untuk menyelenggarakan urusan pemerintahan yang telah diberikan sebagai wewenang daerah.

Pelaksanaan otonomi daerah selain berlandaskan pada acuan hukum, juga sebagai implementasi tuntutan globalisasi yang harus diberdayakan dengan cara memberikan daerah kewenangan yang lebih luas, lebih nyata dan bertanggung jawab, terutama dalam mengatur, memanfaatkan dan menggali sumber-sumber potensi yang ada di daerah masingmasing termasuk kearifan lokal. Keadaan ini merupakan kesempatan yang sangat baik bagi pemerintah daerah untuk membuktikan kemampuannya dalam melaksanakan kewenangan yang menjadi hak daerah. Maju atau tidaknya suatu daerah sangat ditentukan oleh kemampuan dan kemauan pemerintah untuk melaksanakannya. Pemerintah daerah bebas berkreasi dan berekspresi dalam rangka membangun daerahnya, tentu saja dengan tidak melanggar ketentuan perundang-undangan. UU Nomor 23 Tahun 2014 tentang Pemerintahan Daerah menegaskan bahwa otonomi daerah adalah hak, wewenang, dan kewajiban daerah otonom untuk mengatur dan mengurus sendiri Urusan Pemerintahan dan kepentingan masyarakat setempat dalam sistem Negara Kesatuan Republik Indonesia.

Widjaja (2007) mengatakan bahwa prinsip otonomi daerah menggunakan prinsip otonomi seluas-luasnya dalam arti daerah diberikan kewenangan mengurus dan mengatur semua urusan pemerintahan di luar yang menjadi urusan Pemerintah Pusat. Daerah memiliki kewenangan membuat 
kebijakan daerah untuk memberi pelayanan, peningkatan peran serta, prakarsa, dan pemberdayaan masyarakat yang bertujuan pada peningkatan kesejahteraan rakyat.

Pemerintahan Daerah adalah penyelenggaraan urusan pemerintahan oleh Pemerintah Daerah dan Dewan Perwakilan Rakyat Daerah menurut asas otonomi dengan prinsip otonomi seluas-luasnya dalam sistem dan prinsip Negara Kesatuan Republik Indonesia sebagaimana dimaksud dalam UUD 1945. Perangkat Daerah Kabupaten atau Kota menurut UU Nomor 23 Tahun 2014 tentang Pemerintahan Daerah terdiri dari Sekretariat Daerah, Sekretariat Dewan Perwakilan Rakyat Daerah (DPRD), Inspektorat, Dinas, Badan, dan Kecamatan.

Peraturan Pemerintah Nomor 18 Tahun 2016 tentang Perangkat Daerah telah menegaskan bahwa Dinas Daerah merupakan unsur pelaksana urusan pemerintahan yang menjadi kewenangan daerah, yang dipimpin oleh Kepala Dinas dan berkedudukan di bawah dan bertanggung jawab kepada Kepala Daerah melalui Sekretaris Daerah, melaksanakan tugas pokok membantu Kepala Daerah melaksanakan urusan pemerintahan yang menjadi kewenangan daerah dan tugas pembantuan yang diberikan kepada daerah. Dinas mempunyai fungsi: (a) perumusan kebijakan sesuai dengan lingkup tugasnya, (b) pelaksanaan kebijakan sesuai dengan lingkup tugasnya, (c) pelaksanaan evaluasi dan pelaporan sesuai dengan lingkup tugasnya, (d) pelaksanaan administrasi dinas sesuai dengan lingkup tugasnya, dan (e) pelaksanaan fungsi lain yang diberikan oleh Kepala Daerah terkait dengan tugas dan fungsinya.

Pasal 217 dan 218 UU Nomor 23 Tahun 2014 tentang Pemerintahan Daerah dijelaskan bahwa Dinas dibentuk untuk melaksanakan Urusan Pemerintahan yang menjadi kewenangan Daerah, yang diklasifikasikan atas: (a) Dinas tipe A yang dibentuk untuk mewadahi Urusan Pemerintahan yang menjadi kewenangan Daerah dengan beban kerja yang besar, (b) Dinas tipe B yang dibentuk untuk mewadahi 